\title{
Combination of PbFE as an electrochemical sensor and cupferron as a complexing agent for the rapid determination of $\mathrm{Mo}(\mathrm{VI})$
}

\author{
Marzena Adamczyk $^{1} \cdot$ Malgorzata Grabarczyk $^{1}$
}

Received: 27 November 2019 / Accepted: 4 February 2020 / Published online: 24 February 2020

(C) The Author(s) 2020

\begin{abstract}
An analytical procedure regarding the trace determination of molybdenum in natural water samples by adsorptive stripping voltammetry (AdSV) using the in situ plated lead film electrode (PbFE) was described. The method is based on adsorptive accumulation of the $\mathrm{Mo}(\mathrm{VI})$-cupferron complex at the PbFE surface. The optimum analytical conditions include the supporting electrolyte containing 0.2 -mol L ${ }^{-1}$ acetic buffer $\mathrm{pH}=5.3,1.45 \times 10^{-4}-\mathrm{mol} \mathrm{L}^{-1} \mathrm{~Pb}(\mathrm{II})$, and $2.0 \times 10^{-4}$-mol L ${ }^{-1}$ cupferron. A linear response of $\mathrm{Mo}(\mathrm{VI})$ in the concentration range of $3.0 \times 10^{-8}$ to $1.0 \times 10^{-6} \mathrm{~mol} \mathrm{~L}^{-1}(r=0.997)$ was obtained with detection limit of $9.0 \times 10^{-9} \mathrm{~mol} \mathrm{~L}^{-1}$ using accumulation time of $50 \mathrm{~s}$. The selectivity of the method was determined by investigating how the presence of foreign ions affects the determination of molybdenum. The interferences of surface-active substances and humic substances on the molybdenum voltammetric signal were precisely examined and effectively minimized by preliminary mixing with Amberlite XAD-7 resin. The application of the proposed procedure to the analysis of natural water samples was validated by the determination of molybdenum in certificate reference materials SPS-SW1 surface water, Bystrzyca river, tap, and mineral water.
\end{abstract}

Keywords Electrochemical sensors $\cdot$ Molybdenum $\cdot$ Cupferron $\cdot$ Voltammetry $\cdot$ Resin

\section{Introduction}

Molybdenum is a relatively rare heavy trace element found in the soil. It belongs to essential microelements which play an important role in a variety of biochemical and physiological functions in plants, animals, and humans. Molybdenum is a transition element which can exist in several oxidation states ranging from 0 to VI, where VI is the predominant form $\left(\mathrm{MoO}_{4}{ }^{2-}\right)$ found in the environment. Similarly to most metals required for plant growth, molybdenum is utilized by specific plant enzymes to participate in reduction and oxidation reactions. It takes part in the uptake of nitrogen from both nitrogen gas and nitrate [1,2]. This element is an important constituent of several key enzymes and plays a major role in various oxidation-reduction reactions [3]. Molybdenum is utilized by

Marzena Adamczyk

marzena.adamczyk@poczta.umcs.lublin.pl

1 Chemical Faculty, Department of Analytical Chemistry and Instrumental Analysis, Maria Curie-Sklodowska University, M. Curie-Sklodowskiej Sq. 3, 20-031 Lublin, Poland selected enzymes to carry out redox reactions. Enzymes that require molybdenum for activity include nitrate reductase, xanthine dehydrogenase, aldehyde oxidase, and sulfite oxidase [4].Although small amounts of molybdenum are essential to human health, large amounts can be toxic. High doses of molybdenum have been found to produce cellular and tissue damages leading to a variety of adverse effects and human diseases [5]. There is a very narrow range of concentrations between beneficial and toxic [6], so the evaluation of molybdenum level in environmental samples with various matrices, especially in soil and natural water, is needful and highly recommended.

To date, various methods for the determination of molybdenum in environmental samples have been described. Among the available measurement techniques are located cloud point extraction coupled with flame atomic absorption spectrometry [7], graphite furnace atomic absorption spectrometry $[8,9]$, cloud point extraction connected with graphite furnace atomic absorption spectrometry [10], inductively coupled plasma-atomic emission spectrometry [11],inductively coupled plasma-mass spectrometry [12], spectrophotometry [13, 14], and neutron activation analysis [15]. These methods have a number of advantages, first of all, 
excellent sensitivity and good selectivity, but they also have serious drawbacks which include expensive apparatus, pretreatment of real samples, and complicated procedures. The viable alternative to these techniques are electrochemical methods, especially adsorptive stripping voltammetry (AdSV) which provides very low detection limit, good selectivity, and above all, direct determination without the need for application of additional procedures of separation and preconcentration. In the last years, multiple AdSV procedures have been developed for the determination of molybdenum using different complexing agents such as alizarin S [16-18], chloranilic acid [19-24], cupferron [20, 24, 25], 1,10phenanthroline [26], oxine [27, 28], $\alpha$-benzoinoxime [29], morin [30], quercetin [31], tiron [32], pyrogallol red [33], pyrocatechol violet [34], chromoxane cyanine R [35], 2-(2benzothiazolylazo) p-cresol [36], dihydroxynaphthalene [37], and methyl thymol blue [38].

Previous articles showed that in the majority of voltammetric procedures of molybdenum determination, the hanging mercury drop electrode (HMDE) [16, 17, 20, 21, 24, 26-29, 31-37, 39] was used as a working electrode because of its excellent properties. The comparison of parameters of adsorptive stripping voltammetric procedures for molybdenum determination in which hanging mercury drop electrode (HMDE) was used as a working electrode is presented in Table 1. However, in view of mercury toxicity, over the years, HMDE electrodes have been replaced by other more environmentally friendly electrodes. According to literature data, in the case of voltammetric procedures for $\mathrm{Mo}(\mathrm{VI})$ determination, some other types of electrochemical sensors have recently been proposed, among them are lead film electrode [18], renewable mercury film silver based electrode [19], bismuth film electrode [22], bismuth bulk annular band electrode [23], screen printed carbon electrode [25], and modified carbon paste electrode [30].

One of the most common problems of voltammetric techniques is their susceptibility to disturbances related to the presence of organic substances in environmental samples. The main reason for this problem is associated with the adsorption of organic substances such as surface-active compounds onto a sensor, which causes peak reduction or even complete disappearance. Since surface-active substances are an integral part of environmental samples, it is indispensable to develop procedures making it possible to determine $\mathrm{Mo}(\mathrm{VI})$ in environmental samples containing surfactants. Reviewing the hitherto published articles on molybdenum determination by the AdSV method, it was concluded that in many works dealing with this issue, the influence of organic substances on $\mathrm{Mo}(\mathrm{VI})$ determination was not studied at all $[2,16,17,22,30$, $31,34,39]$. In the works in which the problem related to the presence of organic substances was taken into account, it was suggested that in order to eliminate interferences from organic substances, pre-mineralization of the samples by UV irradiation or acid etching in combination with heating before the determination should be performed [18, 19, 35-37]. The authors of some other works proposed the use of Amberlite XAD-7 resin for the same purpose [20, 23].

Up to now, only one AdSV procedure has been developed for the determination of trace molybdenum using lead film electrode (PbFE) sensor as a working electrode. In that work, molybdenum was determined as a complex with alizarin S [18]. In the present article, a new adsorptive stripping voltammetry procedure was applied for the trace molybdenum(VI) determination which was based on adsorptive accumulation of the complexes of molybdenum with cupferron onto the surface of PbFE. This arrangement was proposed for the first time in this work. The most notable advantages of lead film electrodes are lower toxicity and lower background current in the presence of dissolved oxygen as compared with mercury film electrodes. Although lead is toxic too, to test solution was introduced only insignificant amount of this element. Such low concentrations (in our procedure $1.45 \times 10^{-4} \mathrm{~mol} \mathrm{~L}^{-1}$ ) are safe for the laboratory environment. In the case of mercury electrodes, there are volatile mercury vapors that are very harmful and toxic. The use of lead film electrodes is not associated with such a problem.

In order to minimize the negative impact of organic compounds on the molybdenum signal, XAD-7 resins were used. This method of removing organic matter from the sample was used in our previous works and as compared with other methods such as UV irradiation; it seems to be the most effective procedure for eliminating interferences. The developed method was successfully applied to the analysis of natural water samples without their prior preparation.

\section{Materials and methods}

\section{Apparatus}

The measurements were performed using a $\mu$ Autolabanalyzer (Utrecht, The Netherlands). A conventional three-electrode system consisting of a modified glass carbon (GC) with the inner diameter of $1 \mathrm{~mm}$ as the working electrode, a platinum auxiliary electrode, and an $\mathrm{Ag} / \mathrm{AgCl}$ reference electrode (in saturated $\mathrm{NaCl}$ ) was used in all experiments. The $\mathrm{GC}$ electrode was polished on silicon carbide paper ( $\mathrm{SiC}$-paper, \#2500, Buehler, Denmark) and using $0.3-\mu \mathrm{m}$ alumina slurry on a Buehler polishing pad. After polishing, the electrode was washed and sonicated for $30 \mathrm{~s}$ in an ultrasonic bath. The $\mathrm{pH}$ measurements were made on an Elmetron pH meter CI-316. A mechanical stirrer (type RZR 2021, Heidolph, Germany) was used during preliminary mixing analyzed sample with resin. 
Table 1 The comparison of parameters of adsorptive stripping voltammetric procedures for trace molybdenum determination in which hanging mercury drop electrode (HMDE) was used as a working electrode. The procedures are arranged according to the growing detection limit

\begin{tabular}{|c|c|c|c|c|c|c|}
\hline Complexing reagent & Supporting electrolyte & $\begin{array}{l}\text { Linear } \\
\text { range } \\
\left(\mathrm{nmol} \mathrm{L}^{-1}\right)\end{array}$ & $\begin{array}{l}\text { Detection } \\
\text { limit } \\
\left.(\mathrm{nmol} \mathrm{L})^{-1}\right)\end{array}$ & $\begin{array}{l}\text { Accumulation } \\
\text { time }(s)\end{array}$ & Application & Ref. \\
\hline Oxine & $\begin{array}{l}\text { 0.05-M acetate buffer } \mathrm{pH} \\
\quad 3.5\end{array}$ & $0.01-5.0$ & 0.0017 & 60 & Plant foodstuffs & [27] \\
\hline Pyrocatechol violet & $0.08-\mathrm{M} \mathrm{H} 2 \mathrm{SO} 4$ & $0.01-1000$ & 0.002 & 30 & Mineral water, analytical grade acids & [34] \\
\hline Dihydroxynaphthalene & $\begin{array}{l}0.01-\mathrm{M} \text { acetate buffer } \mathrm{pH} \\
\quad 4.7\end{array}$ & $0.01-1.0$ & 0.006 & 60 & Lake water, river water & [37] \\
\hline Methylthymol blue & $\begin{array}{l}\text { 0.1-M phosphate buffer } \\
\text { pH } 2.5\end{array}$ & $0.1-1500$ & 0.02 & 60 & Mineral water, analytical grade salts & [38] \\
\hline Tiron & $0.02-\mathrm{M} \mathrm{KNO}_{3}$ & $0.1-200$ & 0.06 & 60 & $\begin{array}{l}\text { River water, tap water, certified steel references } \\
\text { materials (BS XCCS, BS 2932, IRON 464, } \\
\text { IRON 467), foodstuffs }\end{array}$ & [32] \\
\hline$\alpha$-benzoinoxime & $\begin{array}{l}\text { 0.1-M acetate buffer } \mathrm{pH} \\
\quad 3.0\end{array}$ & $25-100$ & 0.10 & 300 & Mineral water, river water, sea water, & [29] \\
\hline Chloranilic acid & $0.01-\mathrm{M} \mathrm{HCl}$ & $1.7-625$ & 0.16 & 60 & $\begin{array}{l}\text { certified reference surface water, extracts of fly } \\
\text { ashes }\end{array}$ & [21] \\
\hline Chloranilic acid & $\begin{array}{l}\text { 0.1-M acetate buffer } \mathrm{pH} \\
\quad 3.0\end{array}$ & $1.0-100$ & 0.30 & 30 & Certified reference material-seawater NASS-5 & [20] \\
\hline Alizarin red S & - & $1.5-50$ & 0.48 & 20 & Drinking water & 17 \\
\hline Cupferron & $\begin{array}{l}0.05-\mathrm{M} \text { acetate buffer } \mathrm{pH} \\
\quad 3.0\end{array}$ & $1.0-200$ & 0.60 & 60 & River water, tap water, alloy & [24] \\
\hline 1,10-phenanthroline & $\begin{array}{l}0.5-\mathrm{M} \mathrm{NaCl} \text { in } 0.01-\mathrm{M} \\
\mathrm{HCl} \mathrm{pH} 2\end{array}$ & $2.5-500$ & 0.60 & 1200 & - & [26] \\
\hline $\begin{array}{l}\text { 2-(2-benzothiazolylazo) } \\
\text { p-cresol (BTAC) }\end{array}$ & $\begin{array}{l}\text { 0.2-M acetate buffer } \mathrm{pH} \\
\quad 3.5\end{array}$ & $10-100$ & 0.60 & 240 & $\begin{array}{l}\text { Spex mix and Bovine liver (SRM 1777-b) cer- } \\
\text { tified standard }\end{array}$ & {$[3$} \\
\hline Chromoxanecyanine $\mathrm{R}$ & $\begin{array}{l}\text { 0.1-M acetate buffer } \mathrm{pH} \\
3.6\end{array}$ & $1.0-300$ & 0.80 & 60 & River water, tap water, plant foodstuffs & [35] \\
\hline Quercetin & $\begin{array}{l}\text { Britton-Robinson buffer } \\
\quad 0.4 \mathrm{M} \mathrm{pH}=3.7\end{array}$ & $0.9-100$ & 0.90 & 60 & $\begin{array}{l}\text { Synthetic sea water (ASTM D665), tap water, } \\
\text { mineral bottled water }\end{array}$ & [31] \\
\hline Oxine & $0.1-\mathrm{M} \mathrm{HCl}$ & $5.0-1500$ & 1.0 & 60 & $\begin{array}{l}\text { Certified reference seawater samples (CASS-2 } \\
\text { and NASS-2) }\end{array}$ & [28] \\
\hline Pyrogallol red & $\begin{array}{c}\text { 0.06-M Briton-Robinson } \\
\text { buffer solution pH } 2.5\end{array}$ & $8.0-800$ & 1.0 & 90 & River water, tap water, alloy & {$[3$} \\
\hline Alizarin red S & $\begin{array}{l}\text { 0.01-M acetate buffer } \mathrm{pH} \\
\quad 4.0\end{array}$ & $10-260$ & 2.6 & 60 & Tap water seawater, effluent samples & 16 \\
\hline
\end{tabular}

\section{Reagents}

All solutions were prepared using ultra-purified water $(>18$ MVcm) supplied by the Milli-Q system (Millipore, UK). All chemicals used were of analytical reagent grade or Suprapur. The working solutions of Mo(VI) and other foreign ions solutions such as $\mathrm{Zn}(\mathrm{II}), \mathrm{Cd}(\mathrm{II}), \mathrm{Bi}(\mathrm{III}), \mathrm{Ni}(\mathrm{II}), \mathrm{Co}(\mathrm{II}), \mathrm{Cu}(\mathrm{II})$, $\mathrm{Hg}$ (II), $\mathrm{Cr}(\mathrm{III}), \mathrm{Fe}(\mathrm{III}), \mathrm{Ge}(\mathrm{IV}), \mathrm{Mn}(\mathrm{II}), \mathrm{Sb}(\mathrm{III}), \mathrm{Au}(\mathrm{III})$, $\mathrm{Ga}(\mathrm{III}), \mathrm{Pt}(\mathrm{IV}), \mathrm{V}(\mathrm{V})$, and $\mathrm{W}(\mathrm{VI})$ at a concentration of $1 \times$ $10^{-4} \mathrm{~mol} \mathrm{~L}^{-1}$ were prepared by appropriate dilution of 1$\mathrm{g} \mathrm{L}^{-1}$ stock standard solutions in $0.01-\mathrm{mol} \mathrm{L}^{-1} \mathrm{HNO}_{3}$ (Merck). The solution of cupferron at concentrations of $1 \times$ $10^{-2} \mathrm{~mol} \mathrm{~L}^{-1}$ was prepared weekly by dissolving $0.0155 \mathrm{~g}$ of the reagent in deionized water in a $10-\mathrm{mL}$ volumetric flask and was stored in a refrigerator at a temperature of $6{ }^{\circ} \mathrm{C}$. The solutions of $1 \mathrm{~mol} \mathrm{~L}^{-1}$ of the acetate buffers were prepared from Suprapur $\mathrm{CH}_{3} \mathrm{COOH}$ and $\mathrm{NaOH}$ obtained from Merck. A stock standard solution of $1-\mathrm{g} \mathrm{L}^{-1} \mathrm{~Pb}(\mathrm{II})$, polyethylene glycol tert-octylphenyl ether (Triton X-100), cetyltrimethylammonium bromide (CTAB), sodium dodecyl sulfate (SDS), and Rhamnolipid was purchased from Fluka (Buchs, Switzerland). Humic acid sodium salt (HA) was obtained from Aldrich. The river fulvic acid (FA) and natural organic material (NOM) were obtained from the Suwannee River and purchased from the International Humic Substances Society. Certified reference material SPS-SW1 was obtained from the National Research Council, Canada. Amberlite XAD-7 resin was obtained from Sigma, washed four times with ultrapure water, and dried up at a temperature of $50^{\circ} \mathrm{C}$.

\section{General procedure}

Standard measurements were performed using differential pulse adsorptive stripping voltammetry (DP-AdSV) in the following manner. A total of $3 \mathrm{~mL}$ of $1-\mathrm{mol} \mathrm{L}^{-1}$ acetate buffer 
( $\mathrm{pH}=5.3$ ), $300 \mu \mathrm{L}$ of $1 \times 10^{-2}-\mathrm{mol} \mathrm{L}^{-1}$ cupferron, $450 \mu \mathrm{L}$ of 1 -g L ${ }^{-1} \mathrm{~Pb}(\mathrm{II})$, different concentration of $\mathrm{Mo}(\mathrm{VI})$, and an adequate volume of ultrapure water were transferred to the voltammetric cell in order to obtain a $15-\mathrm{mL}$ solution containing $0.2-\mathrm{mol} \mathrm{L}^{-1}$ acetate buffer, $2.0 \times 10^{-4}$-mol L ${ }^{-1}$ cupferron, and $1.45 \times 10^{-4}-\mathrm{mol} \mathrm{L}^{-1} \mathrm{~Pb}(\mathrm{II})$, respectively. The measurements were carried out from underaerated solutions.

Before each measurement, electrochemical cleaning of the GC electrode was performed in the following way: $-1.3 \mathrm{~V}$ for $15 \mathrm{~s}$ and $0.2 \mathrm{~V}$ for $15 \mathrm{~s}$. During the potential of $-1.3 \mathrm{~V}$, the remains from the previous measurement were reduced to the metallic state, and then at $0.2 \mathrm{~V}$ potential, they were stripped from the electrode.

The standard measurement of Mo(VI) determination was carried out, while the potential of the electrode was changed in the following sequence:

(1) $-1.1 \mathrm{~V}$ for $30 \mathrm{~s}$.

(2) $-0.6 \mathrm{~V}$ for $20 \mathrm{~s}$.

(3) $-0.6 \mathrm{~V}$ for $5 \mathrm{~s}$ (equilibration time)

(4) scan from -0.6 to $-0.9 \mathrm{~V}$.

During the first step, a lead film electrode was plated, while during the second step, the Mo(VI)-cupferron complex was accumulated on the electrode. During those steps, the solution was stirred using a magnetic stirring bar. Then after a period of $5 \mathrm{~s}$ without mixing the solution, a differential pulse stripping voltammogram was recorded, while the potential was scanned from 0.6 to $-0.9 \mathrm{~V}$, with the intensity of the obtained peak directly proportional to the concentration of $\mathrm{Mo}(\mathrm{VI})$ in the sample. The scan rate, pulse time, and pulse height were $80 \mathrm{mVs}^{-1}, 2 \mathrm{~ms}$, and $50 \mathrm{mV}$, respectively.

\section{Procedure of elimination of organic substances interferences}

One-milliliter sample solution, $4 \mathrm{~mL}$ of $1-\mathrm{mol} \mathrm{L}^{-1}$ acetate buffer $(\mathrm{pH}=5.3)$ and an adequate volume of ultrapure water, so the final volume of the solution was $10 \mathrm{~mL}$, were added to a glass vial, and finally, $0.5 \mathrm{~g}$ of XAD-7 resin was inserted. Then, a magnetic stirring bar was put into the vial, and the solution was mixed for $5 \mathrm{~min}$ at room temperature. During that time, the organic substances were adsorbed on the resin, while molybdenum (VI) ions remained in the solution. Finally, after sedimentation of the resin, $7.5 \mathrm{~mL}$ of the solution was pipetted into the $15-\mathrm{mL}$ electrochemical cell. Next $300 \mu \mathrm{L}$ of $1 \times$ $10^{-2}$-mol L $\mathrm{L}^{-1}$ cupferron and $450 \mu \mathrm{L}$ of $1-\mathrm{g} \mathrm{L}^{-1} \mathrm{~Pb}$ (II) were inserted into the electrochemical cell, so that the desired concentrations were obtained $\left(0.2-\mathrm{mol} \mathrm{L}^{-1}\right.$ acetate buffer $\mathrm{pH}=5.3,1.45 \times 10^{-4}-\mathrm{mol} \mathrm{L}^{-1} \mathrm{~Pb}$ (II), and $2.0 \times$ $10^{-4}$-mol L ${ }^{-1}$ cupferron).

\section{Results and discussion}

In order to obtain the optimum conditions for molybdenum(VI) determination, the following parameters (affecting the height and shape of the peak) were examined:

- $\mathrm{pH}$ and concentration of the supporting electrolyte,

- the concentration of cupferron,

- the concentration of lead,

- the potential and time of formation of lead film at the electrode surface,

- the potential and time of adsorption of the molybdenumcupferron complex at the electrode surface.

\section{Effect of $\mathrm{pH}$ and concentration of supporting electrolyte}

The supporting electrolyte acetate buffer was studied in the $\mathrm{pH}$ range of 4.0-6.2 for molybdenum determination. Based on literature data, acetate buffer was widely used for the adsorptive stripping voltammetry metal determination using cupferron as a complexing agent $[24,25$, 38-40]. The measurements were performed for the samples containing a constant concentration of $\mathrm{Mo}(\mathrm{VI})$ equal to $5.0 \times 10^{-7} \mathrm{~mol} \mathrm{~L}^{-1}, 2.0 \times 10^{-4}$. mol L ${ }^{-1}$ cupferron, $1.45 \times 10^{-4}-\mathrm{mol} \mathrm{L}^{-1} \mathrm{~Pb}$ (II), and 0.2mol $\mathrm{L}^{-1}$ acetate buffer with different $\mathrm{pH}$ values. The peak current increased with the increase in $\mathrm{pH}$ to 5.3, and above $\mathrm{pH}$ equal to 5.4 , the peak current slightly decreased. Because the maximum peak current was observed for acetate buffer $\mathrm{pH}=5.3$, this supporting electrolyte was chosen for further research.

The effect of acetate buffer of $\mathrm{pH}=5.3$ concentration on the voltammetric peak current of molybdenum was also taken into account. The measurements were performed for the standard solution changing the concentration of acetate buffer in the range from 0.1 to $0.4 \mathrm{~mol} \mathrm{~L}^{-1}$. It was observed that the peak current was growing up with the increase of buffer concentration to $0.2 \mathrm{~mol} \mathrm{~L}^{-1}$. A concentration higher than $0.2 \mathrm{~mol} \mathrm{~L}^{-1}$ did not cause significant changes in the peak height, but the signal was distinctly widened with increasing concentration.

\section{Effect of cupferron concentration}

To choose the optimum quantity of cupferron in the sample, the effect of its concentration on the peak current was studied in the range from $1.0 \times 10^{-5} \mathrm{~mol} \mathrm{~L}^{-1}$ to $7.0 \times 10^{-4} \mathrm{~mol} \mathrm{~L}^{-1}$. The measurements were performed for solutions containing $5.0 \times 10^{-7}-\mathrm{mol} \mathrm{L}^{-1} \mathrm{Mo}(\mathrm{VI}), 0.2-\mathrm{mol} \mathrm{L}^{-1}$ acetate buffer of $\mathrm{pH}=5.3$, and $1.45 \times 10^{-4}-\mathrm{mol} \mathrm{L}^{-1} \mathrm{~Pb}(\mathrm{II})$. The results showed that the peak of molybdenum appeared at a concentration of 
cupferron equal to $5.0 \times 10^{-5} \mathrm{~mol} \mathrm{~L}^{-1}$, then it linearly increased with the increasing concentration of the complexing agent up to $2.0 \times 10^{-4} \mathrm{~mol} \mathrm{~L}^{-1}$, and finally decreased at higher concentrations. So the concentration of $2.0 \times 10^{-4} \mathrm{~mol} \mathrm{~L}^{-1}$ was adopted as the optimum one for further experiments (Fig. 1).

\section{Effect of lead concentration}

The concentration of $\mathrm{Pb}(\mathrm{II})$ in the tested solution is the main chemical factor that determines morphology of the in situ plated lead film and consequently the analytical results. Therefore, this parameter was precisely studied. The AdSV peak current of $5.0 \times 10^{-7}-\mathrm{mol} \mathrm{L}^{-1} \mathrm{Mo}(\mathrm{VI})$ in the presence of $0.2-\mathrm{mol} \mathrm{L}^{-1}$ acetate buffer of $\mathrm{pH}=$ 5.3 and $2.0 \times 10^{-4}$-mol L $\mathrm{L}^{-1}$ cupferron was measured in the function of $\mathrm{Pb}$ (II) concentration over the range $5.0 \times 10^{-6}$ to $4.0 \times 10^{-4} \mathrm{~mol} \mathrm{~L}{ }^{-1}$. It was found that the peak of molybdenum appeared at a concentration of $\mathrm{Pb}$ (II) equal to $2.5 \times 10^{-5} \mathrm{~mol} \mathrm{~L}^{-1}$. At $\mathrm{Pb}$ (II) concentration ranging from $2.5 \times 10^{-5} \mathrm{~mol} \mathrm{~L}^{-1}$ to $1.45 \times$ $10^{-4} \mathrm{~mol} \mathrm{~L}^{-1}$, the peak current of molybdenum increased linearly and finally reached a maximum, and next with the increase of lead concentration, the molybdenum signal progressively decreased. On the basis of these results, the $\mathrm{Pb}(\mathrm{II})$ concentration of $1.45 \times$ $10^{-4} \mathrm{~mol} \mathrm{~L}^{-1}$ was chosen as the optimum one for further research (Fig. 2).

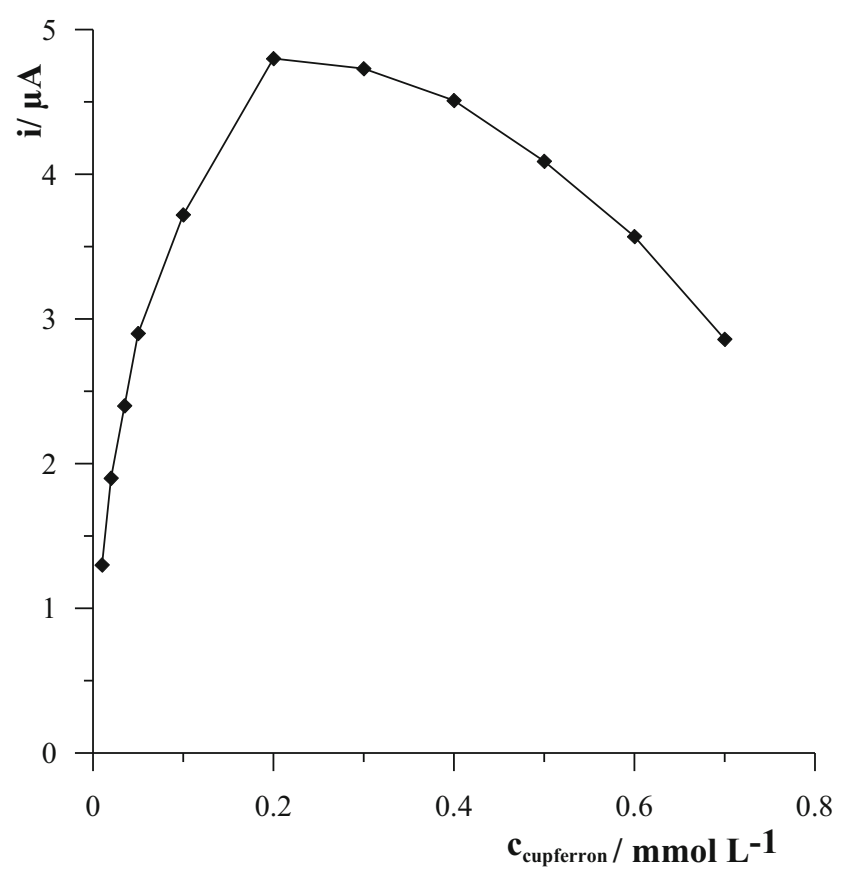

Fig. 1 The influence of cupferron concentration on $5.0 \times 10^{-7}$-mol L $\mathrm{L}^{-1}$ $\mathrm{Mo}(\mathrm{VI})$ voltammetric signal. Concentration of $\mathrm{Pb}$ (II) $1.45 \times 10^{-4} \mathrm{~mol} \mathrm{~L}^{-1}$ and acetate buffer $0.2 \mathrm{~mol} \mathrm{~L}^{-1}(\mathrm{pH}=5.3)$

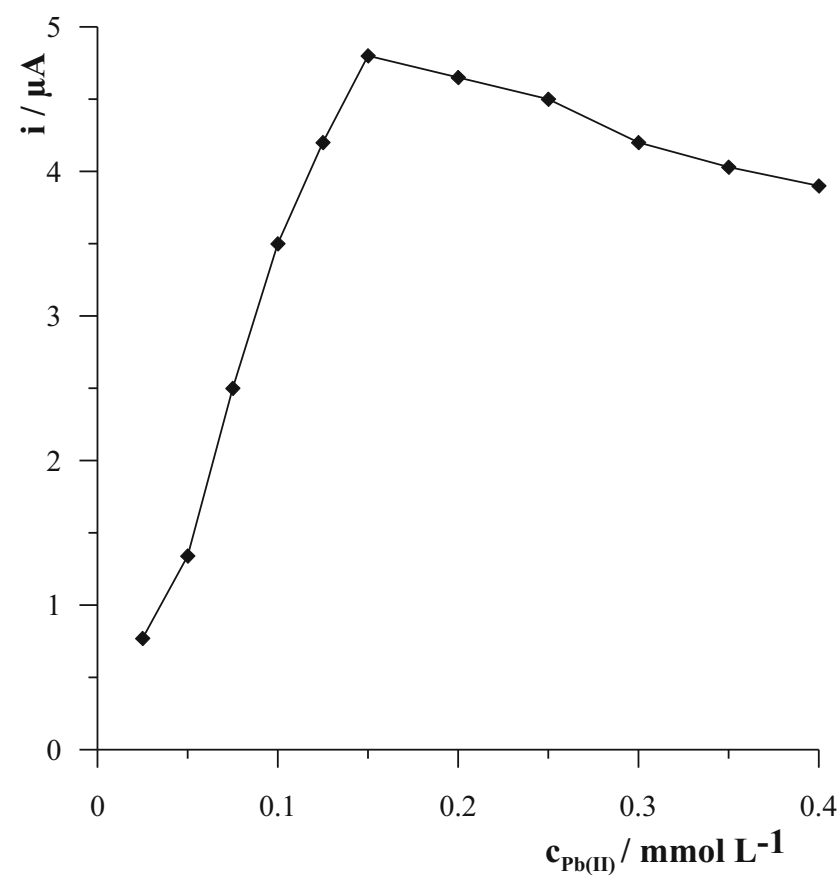

Fig. 2 The influence of lead concentration on $5.0 \times 10^{-7}-\mathrm{mol} \mathrm{L}^{-1} \mathrm{Mo}(\mathrm{VI})$ voltammetric signal. Concentration of cupferron $2.0 \times 10^{-4} \mathrm{~mol} \mathrm{~L}^{-1}$ and acetate buffer $0.2 \mathrm{~mol} \mathrm{~L}^{-1}(\mathrm{pH}=5.3)$

\section{Effect of potential and time of lead film formation and $\mathrm{Mo}(\mathrm{VI})$-cupferron accumulation}

The effect of the electrode potential on lead film formation and $\mathrm{Mo}(\mathrm{VI})$-cupferron accumulation was studied for a solution containing $5.0 \times 10^{-7}-\mathrm{mol} \mathrm{L}^{-1} \mathrm{Mo}(\mathrm{VI})$. On the basis of the performed measurements, it was found that the best signal of molybdenum was obtained by applying a combination of two successive steps: $-1.1 \mathrm{~V}$ for $30 \mathrm{~s}$ followed by $-0.6 \mathrm{~V}$ for $20 \mathrm{~s}$. The optimization of these parameters was carried out by changing the second potential while the first potential was fixed, and then the second potential was fixed while the first potential was modified.

So at first, the potential of Mo(VI)-cupferron accumulation was fixed and was equal to $-0.6 \mathrm{~V}$ and 20 -s accumulation time, while the potential of lead film formation was changed in the range from -1.2 to $-0.7 \mathrm{~V}$ at $30 \mathrm{~s}$. It was stated that for the potential of lead film formation in the range from -1.2 to $-1.0 \mathrm{~V}$, the peak of molybdenum was maximum and constant; for less negative potentials, the peak height slightly decreased. So the potential of $-1.1 \mathrm{~V}$ was chosen as an optimum value. The effect of lead film formation time was tested by changing from 10 to $50 \mathrm{~s}$ using the potential of $-1.1 \mathrm{~V}$. The peak current of molybdenum increased as the film formation time increased to $30 \mathrm{~s}$, and then it was constant.

Next, the potential $-1.1 \mathrm{~V}$ and 30 -s accumulation time were selected for lead film formation, while the potential of $\mathrm{Mo}(\mathrm{VI})$-cupferron accumulation was changed in the range from -0.8 to $-0.4 \mathrm{~V}$ and accumulation time of $20 \mathrm{~s}$. It was 
found that with the changing potential from -0.8 to $-0.6 \mathrm{~V}$, the peak current increased, while further changing the potential towards a less negative value caused a decrease of the peak current. Therefore, the potential of $-0.6 \mathrm{~V}$ for $\mathrm{Mo}(\mathrm{VI})$ cupferron accumulation was selected as the optimum one. The influence of Mo(VI)-cupferron accumulation time was tested from 10 to $50 \mathrm{~s}$ using the accumulation potential of $0.6 \mathrm{~V}$. It was observed that the peak current increases with prolongation of accumulation time up to $20 \mathrm{~s}$, and then it is nearly stable.

\section{Characteristics of the analytical procedure}

The linear range and detection limit of the AdSV response for molybdenum were determined for the solution under the optimum experimental conditions: $0.2-\mathrm{mol} \mathrm{L}^{-1}$ acetate buffer $\mathrm{pH}=5.3,1.45 \times 10^{-4}-\mathrm{mol} \mathrm{L}^{-1} \mathrm{~Pb}(\mathrm{II})$, and $2.0 \times 10^{-4}$ mol L $\mathrm{L}^{-1}$ cupferron using deposition potential $-1.1 \mathrm{~V}$ for $30 \mathrm{~s}$ followed by $-0.6 \mathrm{~V}$ for $20 \mathrm{~s}$. The calibration graph for $\mathrm{Mo}(\mathrm{VI})$ was linear in the range from $3.0 \times 10^{-8}$ to $1.0 \times$ $10^{-6} \mathrm{~mol} \mathrm{~L}^{-1}$ and obeyed the equation $y=9.22 x+0.24$, where $y$ and $x$ are the peak current ( $\mu$ ampere) and concentration of $\mathrm{Mo}(\mathrm{VI})$ ( $\mu \mathrm{mol}$ per liter), respectively. The linear correlation coefficient was $R^{2}=0.997$. Dependence of the stripping peak current on Mo(VI) concentration is shown in Fig. 3 with the corresponding calibration curve. The detection limit estimated from three times the standard deviation at low $\mathrm{Mo}(\mathrm{VI})$ concentration was about $9.0 \times 10^{-9} \mathrm{~mol} \mathrm{~L}^{-1}$. The stability of the proposed method was evaluated by examining the repeatability and reproducibility by performing differential pulse voltammetric measurements for $1.0 \times$ $10^{-7} \mathrm{~mol} \mathrm{~L}^{-1} \mathrm{Mo}(\mathrm{VI})$ under the optimized parameters. The repeatability of the measurements was evaluated from ten subsequent measurements using various solutions as relative standard deviation (RSD) of the highest molybdenum peak values and was equal to $3.5 \%$. The reproducibility was evaluated from the measurements performed in five subsequent days as RSD and was $4.0 \%$.

\section{Effect of foreign ions}

The next stage of the measurements was to study the effect of different metal cations and different inorganic anions on the Mo(VI) analytical signal. The aim of this stage was to show which of the tested ions cause interference, contributing to the reduction of the molybdenum signal, and in some cases even resulting in its complete disappearance.

The effects of co-existing ions were tested using a fixed concentration of $\mathrm{Mo}(\mathrm{VI})$ equal to $5.0 \times 10^{-7} \mathrm{~mol} \mathrm{~L}^{1}$ and different concentrations of several foreign ions. An ion was considered to interfere when its presence produced a variation in the molybdenum peak current $>5 \%$. The results showed that up to a 100-fold excess of $\mathrm{Au}(\mathrm{III}), \mathrm{Co}(\mathrm{II}), \mathrm{Cd}(\mathrm{II}), \mathrm{Cr}(\mathrm{VI})$, $\mathrm{Cu}(\mathrm{II}), \mathrm{Fe}(\mathrm{III}), \mathrm{Ga}(\mathrm{III}), \mathrm{Ge}(\mathrm{IV}), \mathrm{Hg}(\mathrm{II}), \mathrm{In}(\mathrm{III}), \mathrm{Mn}(\mathrm{II})$, $\mathrm{Ni}(\mathrm{II}), \mathrm{Pb}(\mathrm{II}), \mathrm{Pt}(\mathrm{IV}), \mathrm{Sb}(\mathrm{III}), \mathrm{Ti}(\mathrm{IV}), \mathrm{W}(\mathrm{VI}), \mathrm{Zn}(\mathrm{II}), \mathrm{Cl}^{-}$, $\mathrm{NO}_{3}{ }^{-}$, and $\mathrm{SO}_{4}{ }^{2-}$, and 50 -fold excess of $\mathrm{Tl}(\mathrm{I})$ and $\mathrm{Bi}(\mathrm{III}) \mathrm{did}$ not have a significant effect on the Mo(VI) peak. The most interfering ions were $\mathrm{Cr}(\mathrm{III}), \mathrm{Sn}(\mathrm{II})$, and $\mathrm{V}(\mathrm{V})$, whose 50 -fold excess caused a decrease of the molybdenum peak to $40 \%$, $70 \%$, and $80 \%$ of its original value, respectively.

\section{Effect of organic substances}

Because the aim of the proposed procedure was the determination of molybdenum in environmental water samples, investigation of the influence of organic matter was required. The most important components of organic matter present in natural water samples are surface-active substances such as typical industrial pollutants as well as humic substances such as the major components of natural organic matter. All kinds of surfactants, anionic (SDS), cationic (CTAB), non-ionic (Triton X-100), and biosurfactant (Rhamnolipid), were examined in this research. The measurements were performed using General Procedure and Procedure with using Amberlite XAD7 resin for each surfactant separately.

Based on literature data reporting that natural waters contain surfactants with the surface-active effect similar to the
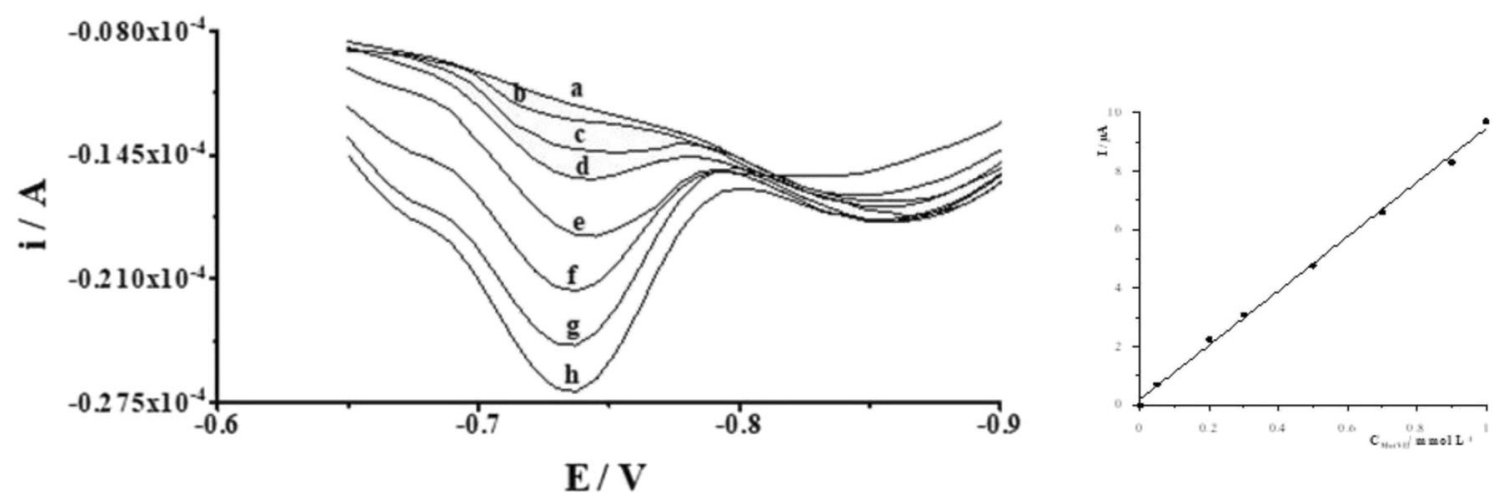

Fig. 3 The voltammograms obtained at the PbFE in the supporting electrolyte containing increasing concentrations of Mo(VI). Concentration of Mo(VI). 0 (a), 0.05 (b), 0.2 (c), 0.3 (d), 0.5 (e), 0.7 (f),

0.9 (g), 1 (h) $\mu \mathrm{mol} \mathrm{L}-1$. Supporting electrolyte $0.2-\mathrm{mol} \mathrm{L}^{-1}$ acetate buffer $(\mathrm{pH}=5.3), 2.0 \times 10^{-4}-\mathrm{mol} \mathrm{L}^{-1}$ cupferron, and $1.45 \times 10^{-4}-\mathrm{mol} \mathrm{L}^{-1} \mathrm{~Pb}(\mathrm{II})$. Inset the corresponding calibration plots 


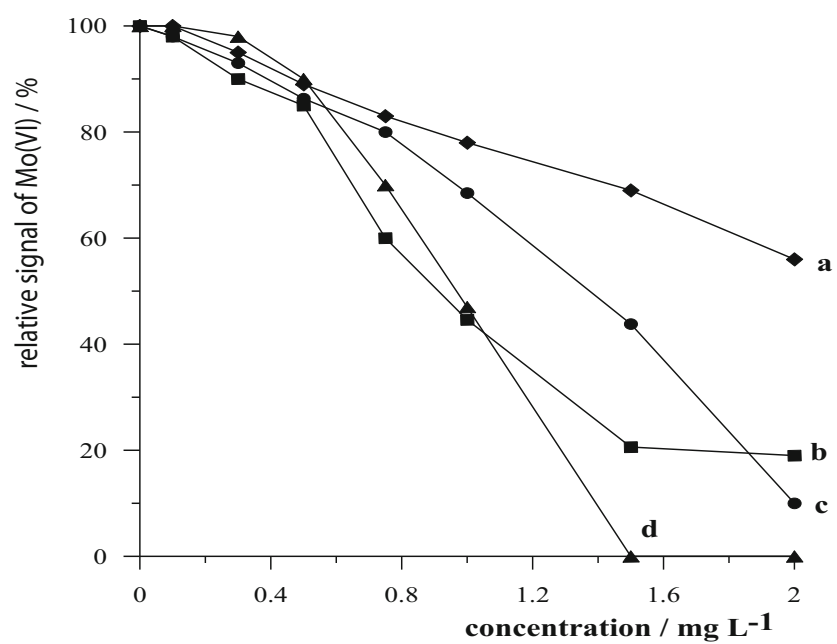

Fig. 4 The influence of Rhamnolipid (a), SDS (b), Triton X-100 (c), and CTAB (d) concentration on the relative signal of molybdenum. Fixed concentration $5.0 \times 10^{-7}-\mathrm{mol} \mathrm{L}^{-1} \mathrm{Mo}(\mathrm{VI}), 0.2-\mathrm{mol} \mathrm{L}^{-1}$ acetate buffer $\mathrm{pH}=5.3,2.0 \times 10^{-4}-\mathrm{mol} \mathrm{L}^{-1}$ cupferron, and $1.45 \times 10^{-4}-\mathrm{mol} \mathrm{L}^{-1} \mathrm{~Pb}(\mathrm{II})$

effect induced by 0.2 to 2 ppm of Triton X-100 [41], we carried out our research using such concentrations of the examined surfactants. Figure 4 presents the influence of SDS, CTAB, Triton X-100, and Rhamnolipid on the voltammetric signal of Mo(VI) obtained using the General Procedure (without elimination of interferences). As can be seen in the case of SDS, Triton X-100, and Rhamnolipid, their concentrations of $2 \mathrm{mg} \mathrm{L}^{-1}$ caused a reduction of the voltammetric signal of molybdenum by about 80,90 , and $45 \%$, respectively. Meanwhile, CTAB at a concentration of $1.5 \mathrm{mg} \mathrm{L}^{-1}$ caused a total loss of the Mo(VI) signal. Using the Procedure with using Amberlite XAD-7 resin (with elimination of interferences), all tested surfactants did not affect the analytical signal in the whole range of concentrations (from 0.2 to $2 \mathrm{mg} \mathrm{L}^{-1}$ ).

\section{Application of proposed procedure}

The proposed method has been validated through Mo(VI) determination in the certified reference material SPS-SW1 surface water (batch 127). This material contains besides molybdenum other trace elements such as $\mathrm{Al}, \mathrm{As}, \mathrm{B}, \mathrm{Ba}, \mathrm{Ca}, \mathrm{Cd}$,

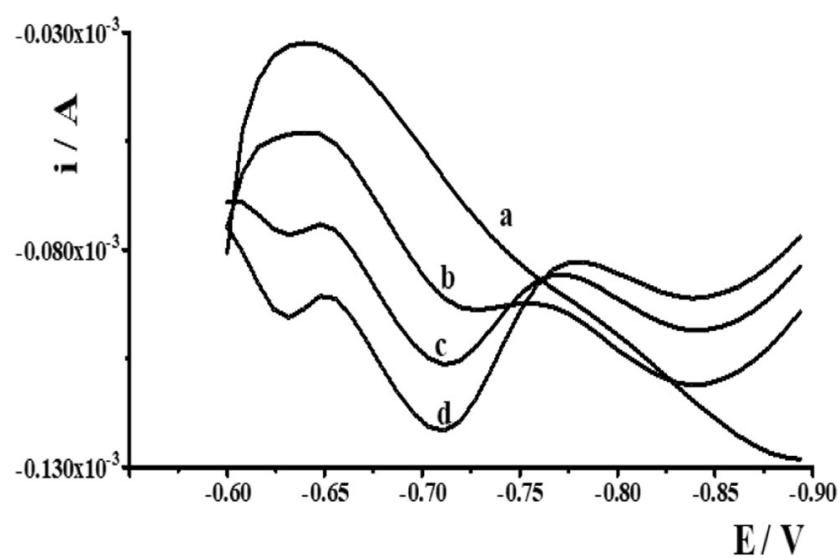

Fig. 5 Differential pulse voltammograms obtained during Mo(VI) determination in the Bystrzyca river water. Diluted ten-fold (a), as (a) + $1.0 \times 10^{-7}-\mathrm{mol} \mathrm{L}^{-1} \mathrm{Mo}(\mathrm{VI})$ (b), as (a) $+2.0 \times 10^{-7}-\mathrm{mol} \mathrm{L}^{-1} \mathrm{Mo}$ (VI) (c), as (a) $+3.0 \times 10^{-7}-\mathrm{mol} \mathrm{L}^{-1} \mathrm{Mo}(\mathrm{VI})(\mathrm{d})$. Fixed concentration. $0.2-\mathrm{mol} \mathrm{L}^{-1}$ acetate buffer $\mathrm{pH}=5.3,2.0 \times 10^{-4}-\mathrm{mol} \mathrm{L}^{-1}$ cupferron, $1.45 \times 10^{-4}$. $\mathrm{mol} \mathrm{L}{ }^{-1} \mathrm{~Pb}(\mathrm{II})$

$\mathrm{Ce}, \mathrm{Co}, \mathrm{Cr}, \mathrm{Cs}, \mathrm{Cu}, \mathrm{Dy}, \mathrm{Er}, \mathrm{Eu}, \mathrm{Fe}, \mathrm{Gd}, \mathrm{Ho}, \mathrm{K}, \mathrm{La}, \mathrm{Lu}, \mathrm{Mg}$, and $\mathrm{Mn}$. The results of determination $(n=3)$ show that the certified value $\left(10.0 \pm 0.1 \mathrm{ng} \mathrm{mL}^{-1}\right)$ and found value $(9.67 \pm$ $0.20 \mathrm{ng} \mathrm{mL}^{-1}$ ) correspond well. Because solution of certified reference material SPS-SW1 contains nitric acid, a proper quantity of sodium hydroxide was added directly to the solution in voltammetric cell in order to neutralize $\mathrm{pH}$.

To confirm the accuracy of the proposed procedure, three fresh natural water samples from the Bystrzyca river water, tap water, and mineral water were collected from eastern part of Poland, and $\mathrm{Mo}(\mathrm{VI})$ determination by the proposed procedure was performed. The voltammograms recorded for those samples did not exhibit any signal of $\mathrm{Mo}(\mathrm{VI})$, which indicated that the concentrations of molybdenum were below the detection limits of the proposed procedure. So, the analyzed samples were spiked with $\mathrm{Mo}(\mathrm{VI})$ at different concentration levels and the molybdenum content was determined by the standard addition method. The obtained results are listed in Table 2 . The typical recorded voltammograms obtained in the course of $\mathrm{Mo}(\mathrm{VI})$ determination in Bystrzyca river are presented in the Fig. 5.
Table 2 Analytical results of $\mathrm{Mo}(\mathrm{VI})$ determination in water samples by proposed standard procedure in the presence of $0.5 \mathrm{~g}$ Ambertite XAD-7 resin. The samples were analyzed after tenfold dilutions using standard addition methods

\begin{tabular}{lllll}
\hline Sample & $\begin{array}{l}\text { Mo(VI) added } \\
\left.(\mathrm{nmol} \mathrm{L})^{-1}\right)\end{array}$ & $\begin{array}{l}\text { Mo(VI) found } \\
(\mathrm{nmol} \mathrm{L})^{-1}\end{array}$ & Recovery $(\%)$ & RSD $(n=5)(\%)$ \\
\hline Bystrzyca river water & 100.0 & 98.8 & 98.8 & 4.6 \\
& 200.0 & 204.8 & 102.4 & 5.2 \\
Tap water & 100.0 & 100.7 & 100.7 & 3.2 \\
& 200.0 & 204.0 & 102.0 & 3.5 \\
Mineral water & 100.0 & 99.4 & 99.4 & 4.3 \\
& 200.0 & 196.0 & 98.0 & 6.1 \\
\hline
\end{tabular}




\section{Conclusions}

The main novelty of the proposed procedure is the application of a new system consisting of an electrochemical sensor, which was PbFE used as a working electrode and cupferron as a complexing agent. The PbFE in situ electrochemically deposited onto a glassy carbon substrate in acid medium occurred to be the right approach to molybdenum determination. The proposed adsorptive stripping voltammetric method offers the advantages of accuracy as well as simplicity of reagents and apparatus. It should be noted that the described procedure is also insensitive to high concentrations of surface-active substances and humic substances thanks to the use of Amberlite XAD-7 resin. To prove its practical applicability, the procedure was successfully tested for the detection of molybdenum in different real water samples.

Open Access This article is licensed under a Creative Commons Attribution 4.0 International License, which permits use, sharing, adaptation, distribution and reproduction in any medium or format, as long as you give appropriate credit to the original author(s) and the source, provide a link to the Creative Commons licence, and indicate if changes were made. The images or other third party material in this article are included in the article's Creative Commons licence, unless indicated otherwise in a credit line to the material. If material is not included in the article's Creative Commons licence and your intended use is not permitted by statutory regulation or exceeds the permitted use, you will need to obtain permission directly from the copyright holder. To view a copy of this licence, visit http://creativecommons.org/licenses/by/4.0/.

\section{References}

1. Kaiser BN, Gridley KL, Brady JN, Phillips T, Tyerman SD (2005) The role of molybdenum in agricultural plant production. Ann Bot 96:745-754

2. Williams RJP, Fraústo da Silva JJR (2002) The involvement of molybdenum in life. BiochemBioph Res Co 292:293-299

3. WHO/FAO/IAEA (1996) Trace elements in human nutrition and health. World Health Organization, Switzerland, Geneva

4. Pita Calvo C, Bermejo Barrera P, Bermejo Barrera A (1995) Determination of molybdenum in human urine by electrothermal atomization atomic absorption spectrometry. AnalChim Acta 310: 189-198

5. Kabata-Pendias A (2001) Trace elements in soils and plants, editor Boca Raton, FL: CRC Press, 3rd

6. Frisbie SH, Mitchell EJ, Sarka B (2015) Urgent need to reevaluate the latest World Health Organization guidelines for toxic inorganic substances in drinking water. Environ Health 14:63 1-15

7. Gürkan R, Aksoy Ü, Ulusoy Hİ, Akçay M (2013) Determination of low levels of molybdenum (VI) in food samples and beverages by cloud point extraction coupled with flame atomic absorption spectrometry. J Food Compos Anal 32:74-82

8. Ferreira SLC, Dos Santos HC, Captos RC (2003) The determination of molybdenum in water and biological samples by graphite furnace atomic spectrometry after polyurethane foam column separation and preconcentration. Talanta 61:789-795

9. Barałkiewicz D, Siepak J (1997) Determination of trace amounts of molybdenum in water samples by graphite furnace atomic absorption spectrometry with multiple injections and cool down step. AnalChim Acta 353:85-89

10. Filik H, Cengel T, Apak R (2009) Selective cloud point extraction and graphite furnace atomic absorption spectrometric determination of molybdenum (VI) ion in seawater samples. J Hazard Mater 169: 766-771

11. Ferreira SLC, Dos Santos HC, de Jesus DS (2001) Molybdenum determination in iron matrices by ICP-AES after separation and preconcentration using polyurethane foam. J AnalChem 369:187190

12. Rodushkin I, Ödman F, Olofsson R, Axelsson MD (2000) Determination of 60 elements in whole blood by sector field inductively coupled plasma mass spectrometry. J Anal At Spectrom 15: 937-944

13. Hoshia S, Konumaa K, Sugawaraa K, Utob M, Akatsukaa K (1997) The spectrophotometric determination of trace molybdenum (VI) after collection and elution as molybdate ion on protonated chitin. Talanta 44:1473-1478

14. Gervasio APG, Fortes PR, Meneses SRP, Miranda CES, Zagatto EAG (2006) An improved flow-injection system for spectrophotometric determination of molybdenum and tungsten in tool steels. Talanta 69:927-931

15. Lavi N, Alfassi ZB (1990) Determination of trace amounts of cadmium, cobalt, chromium, iron, molybdenum, nickel, selenium, titanium, vanadium and zinc in blood and milk by neutron activation analysis. Analyst 115:817-822

16. Jugade R, Joshi AP (2005) Trace determination of Mo(VI) by adsorptive cathodic stripping voltammetry. Acta Chim Slov 52:145148

17. Nakiboğlu N, Sahin I, Tünay Z (2011) Determination of molybdenum by adsorptive catalytic stripping voltammetry in the presence of Alizarin Red S and persulphate. Fresen Environ Bull 20:939-944

18. Tyszczuk K, Korolczuk M (2008) Adsorptive stripping voltammetric determination of trace concentrations of molybdenum at an in situ plated lead film electrode. Anal Chim Acta 624: 232-237

19. Piech R, Baś B, Kubiak WW (2008) The cyclic renewable mercury film silver based electrode for determination of molybdenum(VI) traces using adsorptive stripping voltammetry. Talanta 76:295-300

20. Grabarczyk M, Koper A (2011) Selective, sensitive and economical method for the adsorptive voltammetric determination of trace amounts of $\mathrm{Mo}(\mathrm{VI})$ in organic matter rich environmental samples. Talanta 84:393-399

21. Zarebski J, Bobrowski A, Królicka A, Bobrowski R, Kwaśniewska K (2016) Ultrasensitive catalytic-adsorptive stripping voltammetric determination of molybdenum using a Mo(VI) chloranilic acidchlorate system. Electrochim Acta 208:267-272

22. Wang J, Thongngamdee S, Lu D (2006) Adsorptive stripping voltammetric measurements of trace molybdenum at the bismuth film electrode. Electroanalysis 18:59-63

23. Węgiel K, Grabarczyk M, Kubiak WW, Baś B (2017) Reliable and sensitive voltammetric determination of $\mathrm{Mo}(\mathrm{VI})$ at the in situ renovated bismuth bulk annular band electrode. J Electrochem Soc 164: H352-H357

24. Ensafi AA, Khayamian T, Atabati M (2002) Simultaneous voltammetric determination of molybdenum and copper by adsorption cathodic differential pulse stripping method using a principal component artificial neural network. Talanta 57:785-793

25. Sadeghi S, Garmroodi A (2013) Design and construction of a new modified screen printed sensor for voltammetric determination of molybdenum(VI) ions. Electroanalysis 25:323-330

26. Quentel F (1999) Voltammetric Study of molybdenum in the presence of phenanthroline. Electroanalysis 11:1355-1360

27. Gao Z, Siow KS (1996) Catalytic-adsorptive stripping voltammetric determination of molybdenum in plant foodstuffs. Talanta 43:719-726 
28. Sun YC, Mierzwa J, Lan CR (2000) Direct determination of molybdenum in seawater by adsorption cathodic stripping squarewave voltammetry. Talanta 52:417-424

29. Gao Z, Siow KS (1996) Adsorptive stripping voltammetric determination of traces of molybdenum in natural water in the presence of $\alpha$-benzoinoxime. MicrochimActa 124:211-218

30. Deng P, Feng YI, Fei J (2011) A new electrochemical method for the determination of trace molybdenum(VI) using carbon paste electrode modified with sodium dodecyl sulfate. J Electroanal Chem 661:367-373

31. Rojas C, Arancibia V, Gomez M, Nagles E (2013) Simultaneous determination of antimony(III) and molybdenum(VI) by adsorptive stripping voltammetry using Quercetin as complexing agent. Electroanalysis 25:439-447

32. Ensafi AA, Khaloo SS (2005) Determination of traces molybdenum by catalytic adsorptive stripping voltammetry. Talanta 65:781-788

33. Ensafi AA, Khayamian T, Khaloo SS (2004) Application of adsorptive cathodic differential pulse stripping method for simultaneous determination of copper and molybdenum using pyrogallol red. Anal Chim Acta 505:201-207

34. Zarei K, Atabati M, Ilkhani H (2006) Catalytic adsorptive stripping voltammetry determination of ultra trace amount of molybdenum using factorial design for optimization. Talanta 69:816-821

35. Ensafi AA, Khayamian T, Khaloo SS (2008) Simultaneous determination of trace amounts of vanadium and molybdenum in water and foodstuff samples using adsorptive cathodic stripping voltammetry. Int J Food Sci Tech 43:416-422
36. Fraga LCS, Farias PAM, Ohara AK (2000) Determination of molybdenum in the presence of 2-(2-benzothiazolylazo)-p-cresol by catalytic-adsorptive stripping voltammetry. Fresenius J Anal Chem 366:307-309

37. Li H, Smart RB (1997) Square wave catalytic stripping voltammetry of molybdenum complexed with dihydroxynaphthalene. J Electroanal Chem 429:169-174

38. Korolczuk M, Grabarczyk M (1999) Application of voltammetric method of total chromium determination in the presence of cupferron for selective determination of $\mathrm{Cr}(\mathrm{VI})$ in water samples. Microchem J 62:311-315

39. Safavi A, Shams F (1999) Selective determination of ultra trace concentrations of molybdenum by catalytic adsorptive stripping voltammetry. Anal Chim Acta 396:215-220

40. Koper A, Grabarczyk M (2011) Electrochemical determination of bismuth with use of a $\mathrm{Bi}(\mathrm{III})$-cupferron complexation system and elimination of interferences connected with the presence of organic substances in natural samples. J Electroanal Chem 663:67-71

41. Cosovic B, Vojvodic V (1982) The application of ac polarography to the determination of surface-active substances in seawater. Limnol Oceanogr 27:361-369

Publisher's note Springer Nature remains neutral with regard to jurisdictional claims in published maps and institutional affiliations. 